\title{
Comparative Study Between Using Cooperative Learning Model Teams-Games- Tournaments (TGT) and Direct Instructional Method (DI) to Teach Students' Reading Comprehension
}

\author{
Nurul Ariffa Anggiasari, Muh Asrori, Teguh Sarosa \\ English Education Department \\ Teacher Training and Education Faculty \\ Sebelas Maret University of Surakarta
}

Email: thetruefighter@gmail.com

\begin{abstract}
Mastering reading comprehension is a must for language learners. Without mastering reading comprehension students aren't able to grasp the message on their written form of learning material. Yet, reading comprehension oftenly considered to be difficult by students. This may caused by teacher's method of teaching that doesn't effective. This article compare between the use of Cooperative Learning method model Teams-Games-Tournaments (TGT) and Direct Instructional Method (DI) to teach studentsz reading comprehension. Here describe there is significant difference in reading comprehension achievement between the students taught using TGT and those taught using DI of the eighth grade students of one state junior high school in Grogol, and whether TGT is more effective than DI to teach reading comprehension. The method used in this study is experimental method (comparative study). The population of the research is all the eighth grade students. The sample was taken by using cluster random sampling. Two groups of student were taken, VIII-B as experimental group and VIII-C as control group. The instrument to collect data is test. The data were analyzed using t-test formula. The computation showed that $\mathrm{t}$-observation $\left(\mathrm{t}_{\mathrm{o}}\right)$ is 3.32 consulting $\mathrm{t}$-table ${ }_{(78,0.05)}=1.96$, therefore the $t_{o}$ is higher than $t_{t}$. It is concluded that there's significant difference between experimental and control group. Besides, the mean of the group of students taught using TGT is 62.62, while that of those taught using DI is 59.46, meaning that TGT gives better achievement than DI. Thus, TGT is more effective than DI to teach reading comprehension.
\end{abstract}

Keywords: comparative study, reading comprehension, TGT, direct instruction

\section{INTRODUCTION}

Studying English must be emphasized on the ability to construct and comprehend English sentences in both spoken and written. In English, there are four skills that should be mastered, they are: listening, reading, speaking and writing. For example, reading. Reading is one of four language skills that must be mastered by those who study English. In general, reading is an important, interesting and highly beneficial activity. By reading, people can gather information more widely. They can increase their knowledge trough some pieces of written text only, without having to go anywhere, nor doing research to find the knowledge by themselves. Therefore, reading is known as the activity of opening the window of the world.

In language learning process, reading is a powerful activity that confers knowledge, insight, and perspective on readers (Heath in Aebersold 1997: 6). Reading could be considered as a receptive 
skill, like listening. This is because in reading activity, someone needs to respond the text, rather than produce it. Reading entails to understand the language of text at word level, sentences level and whole text level. Wallace (1996: 2) says that reading is a process whereby one looks out and understands what has been written. Aebersold and field (1997: 15) define that reading is something which people look at the text and assign to the written symbols in that text; in other words, we assume that reading activity is people's activity to read a text.

Even though reading comprehension is essential, many students say they are unsatisfied to their reading comprehension achievement. Therefore, the researcher will find out the problem of reading comprehension and give the solution. The source of problems might be from the students themselves or even from the teacher and materials as well as the method being used in the learning process.

There are some methods can be applied to teach reading comprehension. One of them is Cooperative Learning. According to Johnson (in Isjoni, 2007: 16), cooperative learning is the instructional use of small groups that allows students to work together to maximize their own and each other as learning. In short, cooperative learning is a learning activity in which the students work together to accomplish the objective of learning. It is leaner-centered approach that emphasizes on the success of all of the students, not only high-achieving students succeed but also average and lowachieving students.

A variety of cooperative method has been developed, such as: STAD, TGT, TAI, CIRC, TPS, and the others. One of the methods that can be used in teaching reading is Teams-Games-Tournaments (TGT). TGT is one of cooperative learning type which places students in some learning groups consisting of four to five students who are differs in terms of ability, gender and ethnicity or race, and contains elements of the game and reinforcement. Learning activities using games designed in the TGT model of cooperative learning allows students to learn more relaxedly, and in addition it also fosters responsibility, teamwork, and healthy competition. With the heterogeneity of the group members, it is expected to motivate the students to help each other within the group. Students who have more capability can help students who are less capable to master the subject materials.

TGT were originally developed by David DeVries and Keith Edwards at the University of Johns Hopkins as a cooperative learning method. TGT uses the same teacher presentations and team work as in STAD, but replaces the quizzes with weekly tournaments, in which Students play academic games with members of other teams to contribute points to their team scores.

During the games, students compete individually as representative of their teams against two or three other students of comparable ability. At the games table, the contesting students answer the questions to demonstrate mastery of specific skills. Points are awarded on basis of performance at eah table so that low-acheiving students can score just as many or more points for their teas as high-achieving students

In TGT after the students are devided into teams, they work together with their team-mate. This method is good to provide inter-student cooperativeness in learning as when any members of the group do not 
understand the assignment, the other group members will have the responsibility to provide answers or explanations, before submitting the their team's work sheet to the teacher.

In the other hands, there is Direct Instructional (DI) method. In DI teacher gives explanation, presents the material thereby it can be concluded that DI is also closely related to "lecture and presentation" (Arends, 1997: 64). Nunan (1996: 49) argues ".. in direct instruction, the teacher explicitly instructs the learners". It seems that both Arends and Nunan agree with its name proposed, the essential thing in DI is "instruction". Teacher instructs the students while students listen to teacher's instruction as well as do the required things by teacher. The method views that teacher takes more dominant role in classroom. Teacher is the only one who actively provides explanation and presents the material in the classroom. Consequently, students become more passive. Passive learners have a lot of dependency on their teachers' help and assistance.

Considering the potential benefits of TGT over DI method, the researcher is confident that there is significant difference in teaching reading comprehension between students who are taught using TGT and those who are taught using DI. The researcher also convinced that TGT brings higher result in teaching reading comprehension than Direct Instructional method.

\section{RESEARCH METHODOLOGY}

In this research, researcher performed experimental research. Mason and Bramble (1997:93) define experimental research as the kind of study in which the researcher is interested in learning about the effects of a certain condition (independent variable) and another condition (dependent variables) in controlled setting. In this research the researcher used Posttest Only Control Design of experimental research. In this design, the researcher implemented treatment on the experimental group. The treatment is the independent variable: TGT method in experimental group and old Direct Instructional method in control group. The design of this research can be seen as follow:

\begin{tabular}{|ccc|}
\hline $\mathbf{R}$ & $\mathbf{X}$ & $\mathbf{O}_{1}$ \\
$\mathbf{R}$ & & $\mathbf{O}_{2}$ \\
\hline
\end{tabular}

Where:

$\mathrm{R}$ : Sample in randomized

$\mathrm{X}$ : Treatment

$\mathrm{O}_{1}$ : Post-test for TGT

$\mathrm{O}_{2}$ : Post-test for DI

For this study, a test was used as an instrument for collecting the data. Brown (1994: 252) states that test is method of measuring a person's ability or knowledge in given area. In this research, test was used to measure the students' achievements after given a treatment. So, the test used in this research is achievement test which is designed to measure the degree of learning that has taken place after being exposed to a specific learning experience (Johnson and Christensen, 2000: 117). The achievement test which was used is an objective test of multiple-choice type, because it is easy for the scorer to score and enables the writer to 
measure the effectiveness of specific learning objectives.

To make sure the data that are relevant with the subject matter of the research, the researcher had to perform validation. The validity uses Product moment formula as follows:

$$
\begin{array}{ll}
r_{x y}= & \frac{n\left(\sum X Y\right)-\left(\sum X\right)\left(\sum Y\right)}{\left.\sqrt{\left[n\left(\sum X^{2}\right)-\left(\sum X\right)^{2} n\left(\sum Y^{2}\right)-\left(\sum Y\right)^{2}\right.}\right]} \\
\text { Where: } & \\
r_{x y}= & \text { Coefficient of validity } \\
\mathrm{N}= & \text { Number of Subject } \\
\mathrm{X}= & \text { Score of Item } \\
\mathrm{Y}= & \text { Total Score (Arikunto, 2005:72) }
\end{array}
$$

To find out whether an instrument is reliable and can be used as a device to collect the data with the stability of the test score the researcher used reliability of the test computation. The reliable test is one that

produces essentially the same results consistently on different occasions when the conditions of the test remain the same. To find out the reliability of the test, the formula is as follows:

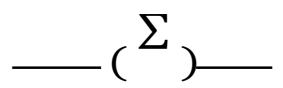

$$
\begin{aligned}
& \text { Where: } \\
& \begin{array}{ll}
\mathrm{r}_{\mathrm{kk}} & =\text { the coefficient of reliability } \\
\mathrm{k} & =\text { number of valid items } \\
\mathrm{p} & =\text { the proportion of the correct answer in each item } \\
\mathrm{q} & =1-\mathrm{p} \\
\mathrm{s}_{\mathrm{t}}{ }^{2} & =\text { the total variance }
\end{array}
\end{aligned}
$$

From the reliability testing, it is obtained that $r_{o}(0.896)$ exceeds $r_{t}(0.312)$ for the level of significance $\alpha=0.05$. It can be concluded that the test is reliable.

Descriptive statistic was used by the researcher as the technique of analyzing the data. Descriptive statistics was used to find mean, median, mode, and standard deviation of the reading score. The formulas of mean, median, and mode are described as follows:

$$
\text { a.Mean }
$$

The mean or average is the sum of all the values in a distribution divided by the number of cases (Ary, 1985: 106). The formula used to determine the mean is:

Where:

$$
\begin{aligned}
- & =\text { the mean } \\
\sum & =\text { the sum of } \\
X & =\text { raw score } \\
n & =\text { the number of cases }
\end{aligned}
$$

b. Median

The median is defined as that point in a distribution of measures below which 50 percent of the cases lie, which means that the other 50 percent will be above this point (Ary, 1985: 103). The median formula is employed: 


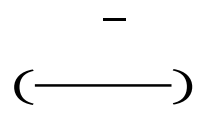

Where:

$\mathrm{M}_{\mathrm{d}}=$ the median

$\mathrm{n}=$ the number of cases in the distribution

$\mathrm{L}=$ the lower limit of the interval within which the median lies

$\mathrm{cfb}=$ the cumulative frequency in all intervals below the interval containing the median

$\mathrm{fw}=$ the frequency of cases within the interval containing the median

$\mathrm{i}=$ the interval size

c. Mode

The mode is that value in a

distribution that occurs most frequently (Ary, 1985: 103). The

formula as follows:

\section{$(\longrightarrow)$}

Where:

Mo $=$ the mode

$\mathrm{L}=$ the lower limit of the interval within which the mode lies

$\mathrm{i}=$ interval (class width0

$f_{i} \quad=$ the frequency of the interval containing mode reduced by that of the previous interval

$\mathrm{f}_{2}=$ the frequency of the interval containing mode reduced by that of the following interval

\section{d. Standard Deviation}

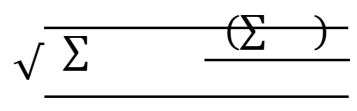

e. Histogram or polygon

A histogram (sometimes referred to a bar graph) is a graph in which the frequencies are represented by bars. A frequency polygon is constructed from the grouped data. In constructing a histogram and a frequency polygon, the scores are grouped into a systematic order that is called as class interval. There are some general guidelines for preparing class intervals; 1) The size of the class interval should be selected and cover the total range of observed scores. 2) The size of the class interval should be an odd number so that the midpoint of the interval is a whole number.
3) It is generally considered good style to start the class interval at a value that is a multiple of that interval (Mahrens, 1973: 82).

In this research, the mean score of post-test on experimental group was compared to the students' mean score of post-test on control group to know whether there was any difference between the reading comprehension of the students eho are taught by using TGT and those who are taught by using DI method. The comparison of the mean score was also used to know wheter TGT give better result to students' reading comprehension compared to DI method. 
Normality test is used to know whether the data have normal distribution or not. In erfiler to test the normality the writer used

follows:

a. Having an observation of $X, X, X, \ldots$ $X_{n}$. The results of $X_{1}, X_{2}, X_{3}, \ldots X_{n}$ become standard number $\mathrm{Z}_{1}, \mathrm{Z}_{2}, \mathrm{Z}_{3}, \ldots$ $\mathrm{Z}_{\mathrm{n}}$ by using the formula ${ }^{-}$is

the average while $\mathrm{S}$ is standard deviation of the sample).

b. Using standard number distribution list for each of the standard number, then count the probability ( ) ( ).

c. Counting of proportion of $Z_{1}, Z_{2}, Z_{3}, \ldots$ $\mathrm{Zn}$ which is less than or equal to $\mathrm{Z}_{\mathrm{i}}$. If the proportion stated by using $S\left(Z_{i}\right)$, so $\mathrm{S}\left(\mathrm{Z}_{\mathrm{o}}\right)$ is the number of $\mathrm{Z}_{1}, \mathrm{Z}_{2}, \mathrm{Z}_{3}, \ldots \mathrm{Z}_{\mathrm{n}}$ which is less than or equal to $Z_{i}$ is divided by $n$.

d. Counting the result of $F\left(Z_{i}\right)-S\left(Z_{i}\right)$ then state the absolute value.

e. Taking the highest value among the absolute values from that result. The maximum result of $F\left(Z_{t}\right)-S\left(Z_{i}\right)$ is $L_{o}$.

Criteria:

$\mathbf{L}_{\mathbf{o}}(\mathbf{L}$ obtained $)>\mathbf{L}_{\mathbf{t}}(\mathbf{L}$ table $)=$ data do not have normal distribution

$\mathbf{L}_{\boldsymbol{o}}(\mathbf{L}$ obtained $) \leq \mathbf{L}_{\mathbf{t}}(\mathbf{L}$ table $)=$ data have normal distribution.

Homogeneity test is used to know whether the data are homogeneous or not. In order to test the homogeneity, the researcher used steps below: a. Computing the $\mathrm{S}$ of each varaince (sample groups: experimental and control groupp) with formula: $s_{i}{ }^{2}=\frac{\sum X_{i}^{2}-\frac{\sum_{i}}{n}}{n-1}$

b. Computing the $S$ merge from the computing step 1 with formula:

$$
s^{2}=\frac{\sum\left\{\left(n_{1}-1\right) s_{1}^{2}\right\}}{\sum\left(n_{1}-1\right)}
$$

c. Find the $\log s^{2}$

d. Computing the B from step c with

$$
\text { formula: } B=\left(\log s^{2}\right) \sum\left(n_{1}-1\right)
$$

e. Computing $)\left\{^{\text {the }}-\chi^{2}\right.$ ( with formula:

$$
\ln 10 B \quad \sum n_{1} \quad 1 \log s_{1}
$$

Where:

$\chi^{2}=$ the homogeneity test

$\mathrm{n}=$ the total samples that is used

$\mathrm{n}_{\mathrm{i}}=$ the total sample in each class

$\mathrm{S}=$ the total variance

Criteria:

$\chi_{o}^{2}<\chi_{\text {table }}=$ the data are homogeneous

$$
\chi_{o}^{2}>\chi_{\text {table }}=\text { the data are not }
$$

homogeneous

As the purpose of the study is to compare between two methods, this study used t-test formula, because one group was taught using Teams-Games-Tournamnts (TGT) and the other using Direct Instructional method. The t-test formula is:

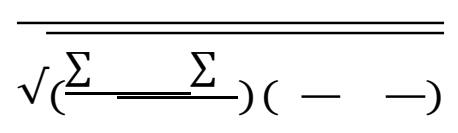

Where:

$\begin{array}{ll}\frac{\mathrm{t}}{X_{1}}-\overline{X_{2}} & : \text { the index of t-test } \\ \sum x_{1}{ }^{2} & : \text { the observed between two means } \\ & \text { : the sum of the square deviation scores in group 1 }\end{array}$




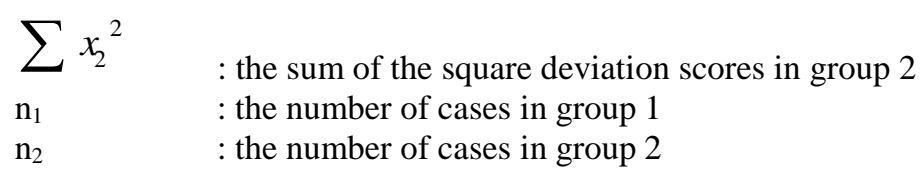

Statistically, the hypothesis could be said as; 1) There is a significant difference in learning achievement of reading between students taught using TGT and those taught D I method. It depends on the comparison between the value of t-test and the value of $\mathrm{t}$-table. If the value of the t-test is higher than t-table, $\mathrm{H}_{\mathrm{o}}$ (Null Hypothesis) is rejected, and it can be concluded that there is a significant difference between students taught using TGT and those taught using DI method. The statistical hypothesis of the research is as follows:

$\mathrm{H}_{\mathrm{o}}$ is rejected if $\left.t_{o}\right\rangle t_{t}$

2) The students taught using TeamsGames-Tournaments (TGT) have higher achievement than those taught using Direct Instructional Method. It is seen from the difference of the mean score of the two groups. The mean score of students taught using Teams-Games-Tournaments (TGT) is higher than the mean score of students taught using Direct Instructional Method.

\section{RESEARCH FINDINGS}

This research was conducted at the eighth grade of a junior high school in Grogol. The class the writer took is VIII B as the experimental group which is taught using Teams-Games-Tournaments (TGT) and VIII $\mathrm{C}$ as the control group which is taught using Direct Instructional method.

The data of the post-test on experimental group showed that the highest score is 83 , while the lowest score is 50 , the mean is 62,65 , the mode is 60 , the median is 60 , and the standard deviation is 13.90 . The distribution of the data can be seen on table 4.1 , the histogram of frequency distribution can be seen in figure 4.1 , and the polygon of frequency distribution can be seen in figure 2

Table 1: The Frequency of Distribution of Post-test Scores of the Experimental Group.

\begin{tabular}{ccclcr}
\hline $\begin{array}{c}\text { Class } \\
\text { limits }\end{array}$ & $\begin{array}{c}\text { Class } \\
\text { boundaries }\end{array}$ & Midpoint & Tally & Frequency & Percentage \\
\hline $50-55$ & $49.5-55.5$ & 52.5 & III & 5 & 15.00 \\
& & & IIIIII & & \\
$56-61$ & $55.5-61.5$ & 58.5 & III & 13 & 41.00 \\
$62-67$ & $61.5-67.5$ & 64.5 & III I & 6 & 19.00 \\
$68-73$ & $67.5-73.5$ & 70.5 & III & 5 & 16.00 \\
$74-79$ & $73.5-79.5$ & 76.5 & II & 2 & 6.00 \\
$80-85$ & $79.5-85.5$ & 82.5 & I & 1 & 3.00 \\
\hline Total & & & & $\mathbf{3 2}$ & $\mathbf{1 0 0}$ \\
\hline
\end{tabular}


Figure 1: The Histogram of the Distribution of Post-test Scores of the Experimental Group.

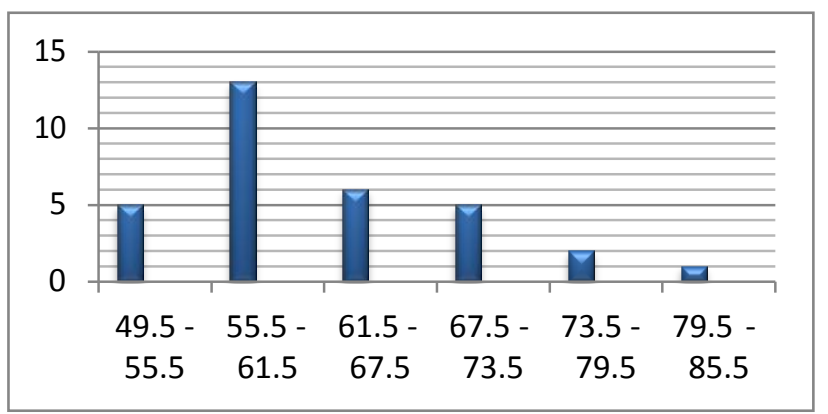

Figure 2: The Polygon of the Distribution of Post-test Scores of the Experimental Group.

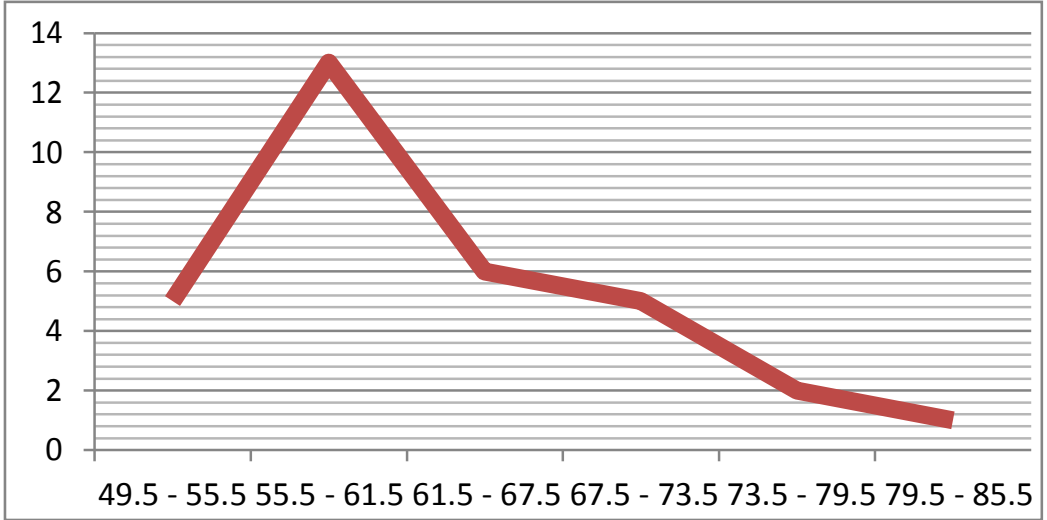

The data of the post-test show that the highest score is 80 , while the lowest score is 43 , the mean is 59,46 , the mode is 66 , the median is 66, and the standard deviation is 9.2. The distribution of the data can be seen on table 4.2 , the histogram of frequency distribution can be seen in figure 4.3, and the polygon of frequency distribution can be seen in figure 4.

\begin{tabular}{ccclcr}
\hline $\begin{array}{c}\text { Class } \\
\text { limits }\end{array}$ & $\begin{array}{c}\text { Class } \\
\text { boundaries }\end{array}$ & Midpoint & Tally & Frequency & Percentage \\
\hline $43-49$ & $42.5-49.5$ & 46 & III & 3 & 9.70 \\
$50-56$ & $49.5-56.5$ & 53 & III III & 8 & 25.80 \\
$57-63$ & $56.5-63.5$ & 60 & IIII & 4 & 12.90 \\
& & & III III & & 38,70 \\
$64-70$ & $62.5-70.5$ & 66.5 & II & 12 & 9.70 \\
$71-78$ & $70.5-78.5$ & 74.5 & III & 3 & 3.20 \\
$79-85$ & $78.5-84.5$ & 81.5 & I & 1 & $\mathbf{1 0 0}$ \\
\hline Total & & & & $\mathbf{3 1}$ & \\
\hline
\end{tabular}


Figure 3: The Histogram of the Distribution of Post-test Scores of the Control Group

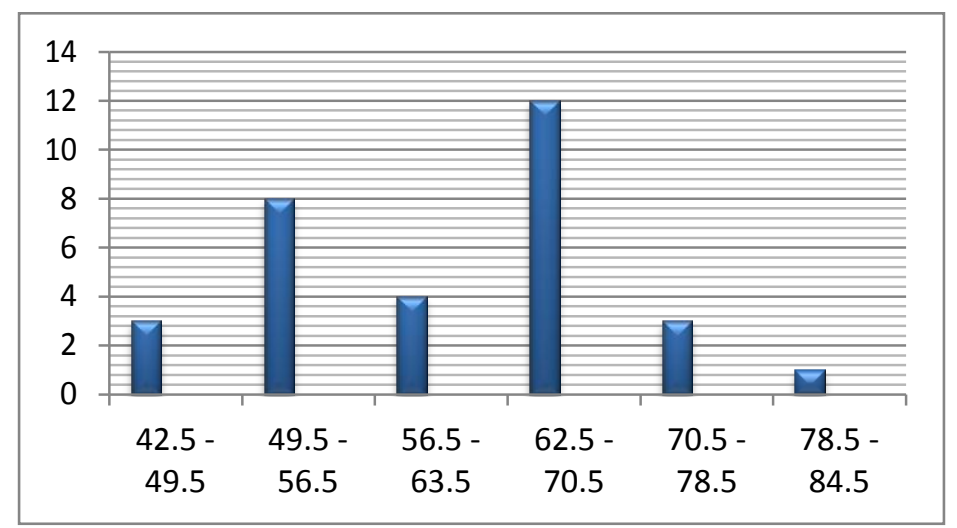

Figure 4: The Polygon of the Distribution of Post-test Scores of the Control Group

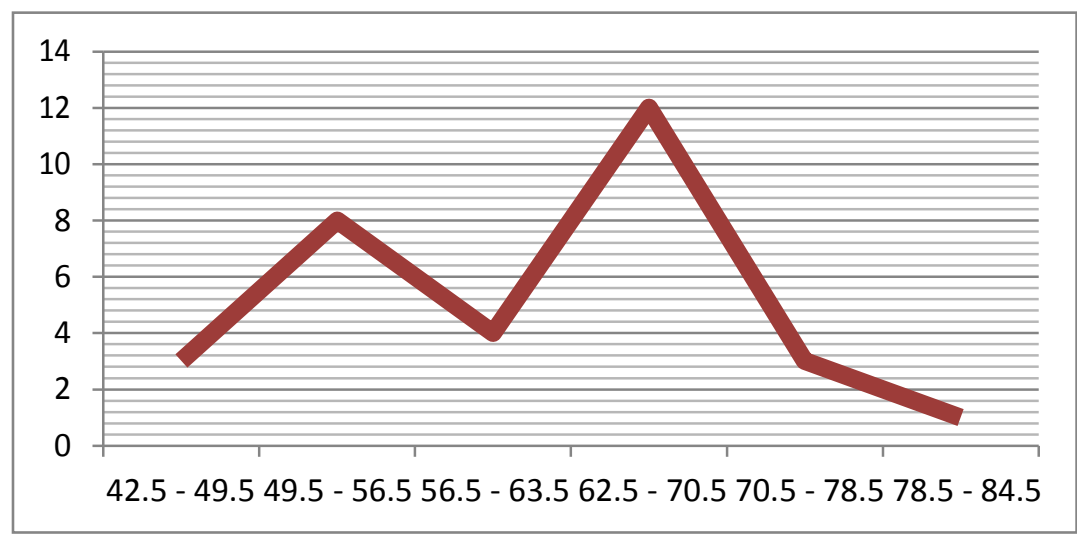

As the requirement of t-test, the data need to be tested for the normality and homogeneity. The normality testing used in this research is Liliefors testing at the level of significance of $0.05(\alpha=0.05)$, while the homogeneity testing used is Bartlet formula at the level of significance of $0.05(\alpha=0.05)$. The result of normality test can be seen on the table 4.3 which presented the summary from the computation of the result.

From the table above, it can be concluded that the data of both experimental group and control group are in normal distribution. In the data of the experimental group, it can be seen that $\mathrm{L}_{\mathrm{o}}$ is 0.1267 . I

$\mathrm{t}$ is then consulted with $\mathrm{L}$ table for $\mathrm{n}=32$ at the level of significance of $0.05(\alpha=0.05)=$ 0.1400 . Because the value of $\mathrm{L}_{\mathrm{o}}$ is lower than $\mathrm{L}$ table $\left(\mathrm{L}_{\mathrm{o}}<\mathrm{L}_{\mathrm{t}}\right)$, it can be concluded that the data of the experimental group are in normal distribution. 
Table 3: The result of normality test for experimental and control groups

\begin{tabular}{ccccccc}
\hline No. & $\begin{array}{c}\text { Teaching } \\
\text { method }\end{array}$ & $\begin{array}{c}\text { Number of } \\
\text { Sample }\end{array}$ & Df & \multicolumn{2}{c}{ L. value } & Conclusion \\
\hline 1. & TGT & 32 & 31 & 0.1267 & 0.1400 & Normal \\
2. & DI & 31 & 30 & 0.1148 & 0.1400 & Normal \\
\hline
\end{tabular}

Meanwhile, the data of the control group shows that $\mathrm{L}_{0}$ is 0.1148 and the $\mathrm{L}$ table for $\mathrm{n}=31$ at the level of significance of $0.05(\alpha=0.05)=0.1400$. Because the value of $\mathrm{L}_{\mathrm{o}}$ is lower than $\mathrm{L}$ table $\left(\mathrm{L}_{\mathrm{o}}<\mathrm{L}_{\mathrm{t}}\right)$, it can be concluded that the data of the control group are in normal distribution.

From the computation of homogeneity test of post-test, it can be seen that $\chi^{2}=$ 0.2516 is lower than $\chi_{(1 ; 0.95)}^{2}=3.841$ or $\chi_{0}^{2}<$ $\chi_{t}{ }^{2}$. Because $\chi_{o}{ }^{2}$ is lower than $\chi_{t}{ }^{2}$, it can be concluded that the data are homogeneous.

The hypotheses the writer has formulated are as follows: first, there is a significant difference in learning achievement of reading between students taught using Teams-Games-Tournaments (TGT) and Dirrect Instructional method, second, the students taught using TeamsGames-Tournaments (TGT) have higher achievement than those taught using Dirrect Instructional method.

To test whether the first hypothesis is accepted or not, the writer uses t-test formula to analyze the data. The data which are analyzed in this research is post-test scores of the two groups, experimental group and control group. The following is the procedures to apply t-test.

a. Determining the degree of freedom

$$
\begin{aligned}
\mathrm{df} & =\mathrm{n} 1+\mathrm{n} 2-2 \\
& =32+31-2 \\
\mathbf{d f} & =\mathbf{6 1}
\end{aligned}
$$

The $t_{\text {table }}\left(t_{t}\right)$ with the level of significance of 0.05 is 1.96 or $\mathrm{t}_{\mathrm{t}(78,0.05)}=1.96$.

b. Applying the t-test

In applying the t-test formula, the researcher tested the null hypothesis $\left(\mathrm{H}_{\mathrm{o}}\right)$ of this research that is there is no significant difference in reading achievement between students taught by using Teams-Games-Tournaments (TGT) and those taught using Direct Instructional method. Statistically, the hypothesis can be formulated as $\mathrm{H}_{\mathrm{o}}$ (Null Hypothesis) : $\mu_{1}=\mu_{2}$.

The alternative hypothesis $\left(\mathrm{H}_{\mathrm{a}}\right)$ of this research is that there is a significant difference in reading achievement between students taught by using Teams-GamesTournaments (TGT) and those taught using Direct Instructional method. Statistically, the hypothesis can be formulated as $\mathrm{H}_{\mathrm{a}}$ (Alternative Hypothesis) : $\mu_{1} \neq \mu_{2}$.

If $t_{0}$ ( $t$ - observation) is smaller than $t_{t}$ $\left(t_{\text {table }}\right)$ or $t_{0}<t_{t}, H_{o}$ is accepted. On the contrary, if $t_{\mathrm{o}}$ ( $\mathrm{t}$ - observation) is higher than $t_{t}\left(t_{\text {table }}\right)$ or $t_{o}>t_{t}, H_{o}$ is rejected.

The result of $t$ computation shows that $\mathrm{t}$ - observation $\left(\mathrm{t}_{\mathrm{o}}\right)$ is 3.32 while the t-table $\left(t_{t}\right)$ for the degree of freedom of 64 and the level of significance $=0.05$ is 1.96 . So, $t_{o}$ is higher than $t_{t}$. It means that $H_{o}$ is rejected. It can be concluded that there is a significant difference in reading achievement between students taught by using Teams-GamesTournaments (TGT) Method and those taught using Direct Instructional method.

The second hypothesis of this research is that the group taught by using TeamsGames-Tournaments (TGT) has a better achievement in reading than those taught using Direct Instructional method. In this case, to test the second hypothesis, the writer needs to compare the post-test mean scores of the two groups. The mean of the scores of the experimental group is 70.03, while the mean of the scores of control 
group is 63.88. The mean score of the experimental group is higher than control group. It can be concluded that TeamsGames-Tournaments (TGT) is more effective than Direct Instructional method.

\section{CONCLUSION AND SUGGESTION}

Based on the result of research, it can be drawn some conclusions as follow; 1) There is a significant difference in teaching reading comprehension between students taught using Teams-Games-Tournaments (TGT) and those who are taught using Direct Instructional method. 2) TeamsGames-Tournaments (TGT) is more effective to be applied in teaching reading comprehension than Direct Instructional method.

The result of the research shows that Teams-Games-Tournaments (TGT) can give better achievement in reading than lecturing method. It means that Teams-GamesTournaments (TGT) is appropriate to be applied in teaching reading for students. The selection of Teams-Games-Tournaments (TGT) is reasonable because it is based on the condition of the students, which mostly are lacked in motivation and only few number of students are high achiever in learning English. Teams-GamesTournaments (TGT) builds more intrinsic motivation by allowing students to play their roles in cooperative group. They have to complete the task and make sure that all members of their group do likewise. Students discuss the material to be learned with another, help one another to understand it, and encourage one another to do their best. They do more activities. Students are actively involved in teaching learning process.

Related to the result of the study that there is a significant difference in the achievement of reading between the students using Teams-Games-Tournaments (TGT) and those taught using Direct Instructional method and that the students taught using Teams-Games-Tournaments (TGT) have higher achievement in reading, the writer would like to give suggestions as follows:

1. To the English Teacher

Teaching English is difficult, so to make the students interested in this subject, the teacher should use various methods in teaching reading. Teacher can choose appropriate method and technique based on the situation. Since this research shows that Teams-Games-Tournaments (TGT) is better than Direct Instructional method for teaching reading, it is recommended for teacher to use Teams-Games-Tournaments (TGT) in teaching reading.

\section{To the Students}

The students should be active in the teaching learning process and do much more practices in the class. The students have to improve their competence of reading with various activities because reading is important to academic success. The students should increase the teamwork among fellow students and help each other while they are learning.

3. To Other Researchers

The writer is aware that her research is not the end of the problem being studied. The result of the study merely confirms the hypothesis; it does not prove that something is absolutely true all the time. Moreover, together with the advanced technology, there must be so many techniques and methods which are found which must be better than current techniques and methods. Thus, the research needs considerable improvement through further research studies. 


\section{BIBLIOGRAPHY}

Aebersold, Jo Ann.\& Field, Mary Lee (1997). From Reader to Reading Teacher: Issues and Strategies for Second Language Classroom. Cambridge: Cambridge University Press.

Arends, Richard I (1997). Classroom Instruction and Management. New York: Mc.Graw Hill Companies. (2005).Learning to Teach ( $7^{\text {th }}$ ed). New York: Mc.Graw Hill Companies.

Brown, H. Douglas. 2004. Language Assessment: Principles and Classroom Practices. New York: Longman.

Isjoni. (2007) Cooperative Learning, Efektifitas Pembelajaran Kelompok. Bandung: Alfabeta.

Kennedy, Eddy C. 1981. Method in Teaching Developmental Reading. Virginia: FE. Peacock Publisher Inc.

Kessler, Carolyn.1992.Cooperative Language Learning: A Teacher's Resource.

Leedy, P. D. 1980. Practical Research Planning and Design. New York : Mac Millan Publishing Inc.

Neuman. 2000. Social Research Methods: Qualitative and Quantitative Approach. Boston, Massachutes: Allyn and Eacon, Inc.

Richards, Jack C \& Rodgers, Thodore (2001). Approaches and Methods in Language Teaching ( $\left.2^{\text {nd }} \mathrm{ed}\right)$.

Cambridge: Cambridge University Press.
Slavin, Robert E (2005).Cooperative Learning: Theory, Research, and Practice. $\left(2^{\text {nd }} e d\right)$. Boston: Allyn and Bacon. 